\title{
Health care utilisation and problems in accessing health care of female undocumented immigrants in the Netherlands
}

\author{
Marianne A. Schoevers • Maartje J. Loeffen • \\ Maria E. van den Muijsenbergh • \\ Antoine L. M. Lagro-Janssen
}

Received: 23 September 2009/Revised: 27 February 2010/ Accepted: 28 February 2010/Published online: 26 May 2010

(C) The Author(s) 2010. This article is published with open access at Springerlink.com

\begin{abstract}
Objective To obtain information about the actual use of health care facilities by undocumented women and to identify obstacles they experience in accessing health care facilities.

Methods A mixed methods study, with structured questionnaires and semi-structured interviews, was chosen to obtain a complete understanding. One-hundred undocumented women were recruited. Diversity was sought according to age, origin and reason for being undocumented. Results Undocumented female immigrants have unmet health care needs $(56 \%)$ and low health care utilisation. Sixty-nine per cent of the women reported obstacles in accessing health care facilities. These included many personal obstacles such as shame, fear and/or lack of information. Poor language proficiency (OR 0.28;. CI 0.09-0.90) reduces utilisation of primary health care services.

Conclusion Health care utilisation of undocumented women is low. Undocumented women refrain from seeking
\end{abstract}

This paper belongs to the special issue "Health of ethnic minorities in Europe".

M. A. Schoevers - M. J. Loeffen - M. E. van den Muijsenbergh ·

A. L. M. Lagro-Janssen

Department Primary Care and Community Care,

Women's Studies Medical Sciences,

Radboud University Nijmegen Medical Centre,

Nijmegen, The Netherlands

M. A. Schoevers $(\bowtie)$

Department Primary Care and Community Care, Centre for Family Medicine, Geriatric Care and Public Health, Radboud University Nijmegen Medical Centre, HAG 117, P.O. Box 9101, 6500 HB Nijmegen, The Netherlands

e-mail: m.schoevers@elg.umcn.nl health care because of personal obstacles. These women need to be identified and informed about their rights, the health care system and the duty of professional confidentiality of doctors. Finally, institutional obstacles to access care should be removed since they strengthen reluctance to seek help.

Keywords Access to health care .

Health services utilisation - Illegal immigrants .

Undocumented immigrants · Women's health

\section{Introduction}

An estimated number of 1.9-3.8 million undocumented immigrants live in Europe (Hamburg 2010). In the Netherlands, estimations range between 75.000 and 185.000 undocumented immigrants (van der Heijden et al. 2006). Undocumented immigrants are people without any residence permit authorising them to stay in the country of their temporary residence. These people experience health problems related to their origin and present situation (Carballo et al. 1998; Carballo and Nerukar 2001; Caulford and Vali 2006; Grove and Zwi 2006; van Oort et al. 2001).

The right to health care is a human right recognised by the UN international covenant on Economic, Social and Cultural rights (United Nations National Assembly 1966). States are under the obligation to provide equal access to preventive, curative and palliative health services for all persons, including undocumented migrants (UN economic saCRC 2000). Despite this, specific legislations, regulations and laws make access to health facilities for undocumented immigrants problematic in many countries (Baghir-Zada 2009; Devillanova 2007; Hall 2007; Kullgren 2003; Kulu Glasgow et al. 2000; Nandi et al. 2008; Okie 2007; 
PICUM 2007; Torres-Cantero et al. 2007; van Oort et al. 2001; Veenema et al. 2009; Wu et al. 2005).

In the Netherlands, undocumented immigrants have no right to obtain health insurance but are entitled to receive "medically necessary care" that is defined as responsible and appropriate medical care as indicated by the treating doctor (Klazinga et al. 2007). At the time of this study, between 2006 and 2008, GPs, midwives and pharmacists could get full reimbursement for unmet costs from a special fund if the undocumented immigrant was insolvent; hospitals could receive reimbursement by means of so-called 'dubious debtors' provisions. Hospitals had to negotiate with health insurance companies about compensation for unpaid bills of insolvent patients. Otherwise, no fund covered ambulant mental care, dental care and residential nursing care. TNO health concluded in 2001, based on interviews with health care professionals, that these financial arrangements in general raise no obstacles accessing health care (van Herten et al. 2001). Nevertheless, serious doubts about the accessibility of health care for undocumented immigrants remain.

Health care seeking behaviour and access to health care are influenced by many factors other than legal and financial (Berk and Schur 2001; Stronks et al. 2001; Uiters et al. 2006). Most information about access to health care in undocumented immigrants in earlier studies was obtained from health care institutions and health care professionals (Delvaux et al. 2001; Kulu Glasgow et al. 2000; PICUM 2007; van Oort et al. 2001; Veenema et al. 2009; Wolff et al. 2008; Wu et al. 2005). In order to understand the problems in accessing health care and influencing factors, research among the population of undocumented immigrants themselves is necessary. Unfortunately, these data are scarce (Baghir-Zada 2009; Devillanova 2007; Nandi et al. 2008) as the World Medical Organisation (WMA) recently concluded (Storwick 2009). Therefore we decided to study this gap in the knowledge.

We focussed on undocumented women since in comparison with male persons their vulnerability is even greater and data about access to health care are even scarcer. Undocumented women have many different health problems and rate their health as very poor (Schoevers et al. 2009). Especially, gynaecological and psychosocial problems are prevalent. Therefore, adequate access to health care facilities is important for females. We were particularly interested in the experiences of women who were not in contact with health care professionals. Therefore, we decided to recruit and interview different undocumented women from different backgrounds. Our aim was to obtain information about the obstacles faced by undocumented women in accessing health care facilities and about the extent of the problem: the actual use of health care facilities by this group.

\section{Methods}

Study design

We opted for a mixed method study, with a structured questionnaire about the use of health care services and a semi-structured interview about obstacles experienced in accessing health care. Tracing undocumented immigrants and conducting research in this group is time-consuming and very difficult. Participants' trust should be gained and their safety should be guaranteed. Obtaining quantitative data about the use of health care facilities and qualitative data about obstacles in accessing health care facilities at the same time was efficient and implicated minimum inconvenience for the participants. But more important, this method provides a better understanding of the problem. We used a triangulation design model, with equal priority for qualitative and quantitative data (Creswell et al. 2004). Participants were purposively recruited.

This study was part of a larger project that evaluated the feasibility of introducing patient-held records for undocumented immigrants.

\section{Study population}

Undocumented women aged $\geq 18$ years, living in different parts in the Netherlands, were purposively recruited through voluntary support organisations, general practitioners (GPs), a domestic workers organisation, shelter homes, churches and midwives. To find women not yet identified by health professionals or an organisation, advertisements were placed in local newspapers and recruiting posters were placed in locations frequented by immigrants. Further, we made use of snowball sampling: we asked participants with whom contact had been established to refer to us other females who could potentially participate. After successfully enrolling 80 women this way, we stopped the recruitment and we evaluated the composition of the study population. Variation in age, country of origin and reason for being undocumented was judged. After that we exclusively looked for undocumented women that were underrepresented in the study population according to the estimates of different groups of undocumented women in the Netherlands: undocumented labour migrants and victims of human trafficking (van der Heijden et al. 2006).

Undocumented women that contacted us and showed interest to participate in our study received an explanatory letter in their own language. The research assistant contacted all women by telephone to clarify the purpose of the study more in detail. If the women agreed to participate an appointment for an interview was made.

We provided all participants with free medical advice and assisted in finding a GP. 
Data collection

Interviews were conducted in primary health care facilities or in the person's temporary shelter. The interviewer was a skilled research assistant. To women that were unable to communicate in English or Dutch sufficient interpretation was offered. The participants were informed that their answers would be processed anonymously. Given the fact that it was very difficult to gain the trust of the women as many of them were afraid of being arrested by the police, we decided not to audiotape the interviews. Socio-demographic information was obtained at the start of the interview and included data about country of birth, marital status, children, housing conditions, occupation, education, duration of residence in the Netherlands and reason for staying in the Netherlands. Data about use of health care services were obtained through a structured questionnaire. In order to explore obstacles experienced in accessing health care, a semi-structured interview was held. The interviewer followed an interview guide composed by an expert panel. The interview guide contained the following themes: reasons for not-using health care facilities and obstacles encountered in accessing facilities. Field notes were made and member checking took place after the interview.

\section{Data analysis}

Data analysis was performed after all data (i.e., both qualitative and quantitative data) had been collected: parallel/simultaneous design.

The quantitative data were analysed using SPSS for windows (version 16.0, Spss Inc, USA).

Two-tailed Pearson Chi-square tests were used to examine the relations between use of different health services and the following variables: age, marital status, having children or not, country of origin, employment status, capability of speaking Dutch, duration of undocumented stay in the Netherlands, reason for staying in the Netherlands and self-rated health. Multivariate logistic regression analyses were performed by entering all variables that reached $p$ values $<0.20$ in univariate analysis, to identify the factors that were independently associated with the use of health services.

Two authors (MS and ML) independently analysed the data of the semi-structured interviews. After familiarisation with the data, the researchers carried out thematic analyses to identify and categorise major themes and subthemes. The notes, field notes and transcripts were independently coded and subsequently the researchers defined the most important themes together. In case of disagreement both researchers tried to reach consensus by discussion. In case of a remaining dispute a third researcher (MvdM) was consulted.

Approval from the study was obtained from the Radboud University Nijmegen Medical Centre Ethical Committee (nr: CMO 2005/204).

\section{Results}

Of the 100 women participating in the study, 47 lived in a semi-rural area in the south east of the Netherlands (Nijmegen, Den Bosch) and 53 in a large city (Amsterdam, Rotterdam, The Hague) (Table 1).

For 13 women we used a qualified interpreter and for 24 women a relative was interpreting. Though we preferred to interview the women alone, 50 women came, for practical or security reasons, to the interview accompanied by one or more children (9), their partner (12), a volunteer (5), a female family member or friend (20) or a male family member or friend (4). In order not to lose the trust of the women we allowed these companions to attend the interview.

Table 1 Characteristics of study population $\% /$ mean (SD) $(n=100)$

\begin{tabular}{|c|c|}
\hline Age $(\text { years })^{\mathrm{a}}$ & $36.4(14.7)$ \\
\hline Children & 73 \\
\hline \multicolumn{2}{|l|}{ Partner } \\
\hline Yes & 53 \\
\hline \multicolumn{2}{|l|}{ Religion } \\
\hline Christian & 62 \\
\hline Muslim & 23 \\
\hline Hindu & 3 \\
\hline Buddhist & 2 \\
\hline No religion & 10 \\
\hline \multicolumn{2}{|l|}{ Country of origin } \\
\hline Europe & 37 \\
\hline Asia & 29 \\
\hline Africa & 25 \\
\hline America & 9 \\
\hline \multicolumn{2}{|l|}{ Reason to come to Netherlands } \\
\hline Political reasons & 57 \\
\hline Non-political reasons & 43 \\
\hline \multicolumn{2}{|l|}{ Employment status } \\
\hline Unemployed & 80 \\
\hline Full time or par time job & 20 \\
\hline \multicolumn{2}{|l|}{ Literacy } \\
\hline Difficulties reading and writing & 19 \\
\hline Mean duration of residence in Netherlands in years & $5.55(3.2)$ \\
\hline Mean duration of residence without documents in years & $2.86(3.0)$ \\
\hline
\end{tabular}

${ }^{a}$ One missing, did not know age 
Use of health care facilities

Eighty percent of the women mentioned to have experienced health problems during their stay as undocumented immigrant. $39 \%$ (31) of these women received medical care for these problems, 56\% (45) said they received no care for these problems, and $5 \%$ (4) reported that they received care for some problems but not for all.

\section{Registration with a GP}

$56 \%$ (56) of the women were registered with a GP. Women that were supported by (voluntary) support organisations were registered with a GP in $81 \%$ (46) of the cases, and women not supported by (voluntary) support organisations in $23 \%(10)(p=0.000)$.

Almost all women that were registered (40) found their GP with help of a voluntary support organisation; eight women found a GP through family members or friends, the others through churches, employers, other doctors and public health institutions.
Use of health care

Undocumented women that came to the Netherlands for political reasons (rejected asylum seekers) reported higher health care utilisation than women that came to the Netherlands for personal or economic reasons (Table 2).

Table 3 shows adjusted ORs for the associations between characteristics of the study population with $p<0.2$ in univariate analysis and contact with a GP $<2$ months.

Women that did not speak the Dutch language reported fewer contacts with a GP (OR 0.28; CI 0.09-0.90). Women that rated their health as "poor" (moderate or bad) reported significantly more contacts with GPs in comparison with women that rated their health as "good" (good, very good or excellent) (OR 4.89; CI 1.56-15.30). On the contrary, women that rated their health as "poor" reported fewer consultations with medical specialists in comparison with women that rated their health as good (OR 0.26; CI 0.080.77) (Table 4).

Table 2 Differences in the use of health care services between undocumented immigrants for political and non-political reasons $\%(n)$

\begin{tabular}{|c|c|c|c|c|}
\hline & $\begin{array}{l}\text { Total studied } \\
(n=100)\end{array}$ & $\begin{array}{l}\text { Undocumented for political } \\
\text { reasons }(n=57)\end{array}$ & $\begin{array}{l}\text { Undocumented for } \\
\text { non-political reasons }(n=43)\end{array}$ & $p$ value \\
\hline No use of professional health care services $<1$ year & $13(13)$ & $7(4)$ & $21(9)$ & 0.041 \\
\hline Contact general practitioner $<2$ months & 49 (49) & $63(36)$ & $30(13)$ & 0.001 \\
\hline Contact outpatient specialist ever while undocumented & $33(33)$ & $35(20)$ & $30(13)$ & 0.609 \\
\hline Contact with ambulatory mental health care $<1$ year & $19(19)$ & $32(18)$ & $2(1)$ & 0.001 \\
\hline Contact dentist $<1$ year & $33(33)$ & $42(24)$ & $21(9)$ & 0.026 \\
\hline
\end{tabular}

Table 3 Self-reported contact with GP in the last 2 months: logistic regression

Each variable had been adjusted for all other variables in the table

$O R$ odds ratio, $C I$ confidence interval

$* p<0.05$

\begin{tabular}{|c|c|c|}
\hline Characteristic & Unadjusted OR (95\% CI) & Adjusted OR (95\% CI) \\
\hline Age & $1.03(1.00-1.06)$ & $1.02(0.99-1.06)$ \\
\hline \multicolumn{3}{|l|}{ Country of origin in } \\
\hline Asia & $0.29(0.10-0.81)^{*}$ & $0.42(0.12-1.42)$ \\
\hline Africa & $0.96(0.34-2.71)$ & $1.65(0.44-6.11)$ \\
\hline America & $0.32(0.07-1.48)$ & $0.37(0.04-3.09)$ \\
\hline Europe & Ref & Ref \\
\hline \multicolumn{3}{|l|}{ Language proficiency in Dutch } \\
\hline Poor & $0.36(0.16-0.80)^{*}$ & $0.28(0.09-0.90)^{*}$ \\
\hline Good & Ref & Ref \\
\hline \multicolumn{3}{|l|}{ Self-rated health } \\
\hline Moderate/poor & $4.44(1.78-11.05)^{*}$ & $4.89(1.56-15.30)^{*}$ \\
\hline Good/very good/excellent & Ref & Ref \\
\hline \multicolumn{3}{|c|}{ Reason for stay in the Netherlands } \\
\hline Political reasons & $4.15(1.77-9.77)^{*}$ & $2.12(0.65-6.91)$ \\
\hline Non-political reasons & Ref & Ref \\
\hline
\end{tabular}


Table 4 Self-reported contact with specialist while undocumented: logistic regression
Each variable had been adjusted for all other variables in the table

$O R$ odds ratio, $C I$ confidence interval

$* p<0.05$

\begin{tabular}{lll}
\hline Characteristic & Unadjusted OR $(95 \%$ CI $)$ & Adjusted OR (95\% CI) \\
\hline Age & $1.03(1.00-1.06)$ & $1.05(1.02-1.09)^{*}$ \\
Country of origin in & & \\
Asia & $0.90(0.31-2.64)$ & $1.62(0.47-5.54)$ \\
Africa & $1.33(0.45-3.91)$ & $2.50(0.68-9.16)$ \\
America & $2.96(0.67-13.13)$ & $6.50(0.87-48.58)$ \\
Europe & Ref & Ref \\
Language proficiency in Dutch & & $0.38(0.13-1.14)$ \\
$\quad \begin{array}{l}\text { Poor } \\
\text { Good }\end{array}$ & $0.41(0.18-0.97)^{*}$ & Ref \\
Self-rated health & Ref & \\
Moderate/poor & & $0.26(0.08-0.77)^{*}$ \\
Good/very good/excellent & Ref & Ref \\
Reason for stay in the Netherlands & & $1.87(0.54-6.50)$ \\
Political reasons & $0.80(0.34-1.87)$ & Ref \\
Non-political reasons & Ref & \\
\hline
\end{tabular}

Obstacles in accessing health care facilities

Sixty-nine women (69\%) reported problems in accessing health care facilities. We identified two different categories of problems: (1) Institutional obstacles: obstacles put in place by health care facilities or aid organisations and (2) personal obstacles in accessing care; these are hindrances as felt by the person herself.

Forty-seven women $(47 \%)$ reported institutional obstacles and 40 women $(40 \%)$ reported personal obstacles. Eighteen women reported problems from both categories.

Institutional obstacles included:

Financial barriers

Invoices (up to 7,000 euro) were received from hospitals. Some women were confronted with a debt collection agency. These occurrences had a negative influence on their future health-seeking behaviour:

"I do not have enough money to go back to the hospital."

Forced cash payment was experienced in primary care and at the pharmacy:

"I had to pay 75 euro before they even wanted to look at my sick child"

"I was forced to pay the doctor, after that I never went back".

Women reported that operations, maternity care, examinations and nursing aid were cancelled since they were not insured and it was considered to be too costly.
Refusal of services

In primary care women were refused admission, as a patient, by the receptionist or by the GP in person, since they were unable to show identification papers:

"You are no longer insured, so you won't get an appointment" (GP to a patient who lost her temporary residence permit).

Further, numerous women were refused help in an institution of secondary care:

"I had a surgery appointment for cervix carcinoma. But when I arrived at the hospital on the scheduled day I was sent away by the receptionist. I felt deeply humiliated."

The mediation by volunteers was reported as an obstacle as well, in particular the need for authorisation by the support organisation to go to the doctor:

"Appointments with the GP are made by the volunteer. This is unpleasant, because I need to tell her what my problem is..."

Personal obstacles in accessing care included the following:

\section{Lack of information}

Women were not informed about their entitlements:

"I was not aware that it was possible for me to go to a doctor"

Furthermore, women experienced problems finding their way around in the Dutch health system: 
"I did not know where to go, we did not know how things were organised, absolutely nothing and it was so difficult..."

Fear for bills

This was an important obstacle in accessing health care. Many never visited a doctor for this reason.

"I never consult a doctor, because I have no money.

Fear for being reported to the police

"I was afraid that the doctor would contact the police"

"I was too afraid to go to a dentist. Finally when I could no longer bear the pain I pulled the tooth out myself."

Women were not informed that a health care professional in the Netherlands has an obligation of professional confidentiality and will not contact the police authorities.

Sense of shame

"It feels bad if you have to ask for help without being able to pay for it"

Health care no priority

For other women searching for food and shelter took all their energy. A woman who delivered without one single ante natal check mentioned:

"There were so many problems, I struggled to survive, I didn't even realise I could go to a doctor."

\section{Discussion}

Health care utilisation of undocumented female immigrants in our study is low. The majority of the women report unmet health needs (56\%) and obstacles in accessing health care $(69 \%)$. These included many individual obstacles such as fear, shame or lack of information.

There is evidence that health care utilisation by the undocumented women in our study is lower than that by legal migrant women and female asylum seekers/refugees in the Netherlands (Gerritsen et al. 2006; van Lindert et al. 2004). This applies particularly to women that came to the Netherlands for personal reasons such as marriage and reunion with family or for economic reasons. Fifty-six percent of legal immigrant women had contact with a GP in the past 2 months versus $49 \%$ of our total study population and $30 \%$ of undocumented women that came to the Netherlands for non- political reasons. Contacts with medical specialists were even less frequent: 58.5 versus 33 and 30\% (van Lindert et al. 2004). The higher use of health care facilities by women that came to the Netherlands for political reasons (rejected asylum-seekers) can be partly explained by a better understanding of the Dutch health care system; during their stay in the asylum seekers centres they were entitled to regular health care and received information about the Dutch health care system. Also their contacts with voluntary support organisations may contribute to this difference; these organisations play an important role in assisting undocumented immigrants to access health care in the Netherlands.

Factors associated with use of health services are age, language problems and self-rated health. The association between older age and increased health utilisation was found in other studies as well (Reijneveld 1998; van Lindert et al. 2004). Language problems also influenced the health-seeking behaviour (Nandi et al. 2008; Wallace et al. 2009; Wu et al. 2005) of Mexican immigrants and Canadian immigrants in the US. The association between poor self-rated health and health care utilisation, however, is contradictory. Poor self-rated health was associated with more consultations with a GP, but with fewer consultations with medical specialists. Associations between poor selfrated health and increased health care utilisation are known from other studies (DeSalvo et al. 2005; Gerritsen and Deville 2009; Reijneveld 1998; Uiters et al. 2009). The association between poor self-rated health and lower secondary care utilisation is new and surprising. Some studies report lower use of secondary care facilities by immigrants (Hernandez-Quevedo and Jimenez-Rubio 2009; Stronks et al. 2001) and others a higher use (Lanting et al. 2008; van Lindert et al. 2004), but no studies report lower use by patients with poor self-rated health. Further studies are recommended to explore this detail.

Lower health care utilisation can be a problem for accessibility or can reflect differences in need. Our study clearly shows that problematic access to health care facilities for undocumented women is the main reason for the lower use. In our study population only $39 \%$ of the women expressed that they received adequate medical care for the health problems they experienced during their undocumented stay. Sixty-nine percent of the women report problems in accessing health care facilities. These problems subscribe the obstacles mentioned in several reports: rejection by GPs and specialists, discrimination, neglect, cancellation of surgeries and invoices (Kulu Glasgow et al. 2000; PICUM 2007; Veenema et al. 2009). Our study emphasises, however, also the influence of other than institutional blockades. Many undocumented women will never seek help due to personal blockades like fear for bills and deportation, shame and language problems. An important common cause of all the above-mentioned individual blockades is a lack of information. Women were 
found poorly informed about their rights and entitlements, the Dutch health care system and the possibility of reimbursement for the health care professionals. These findings are in conformity with a recently published thesis of BaghirZada who interviewed 25 undocumented women about health needs (Baghir-Zada 2009). Bills presented to women by GPs, midwives and pharmacists indicate that health care workers are not adequately informed about existing legislation and/or reimbursement of costs either.

There are some limitations in our study design and data collection. For the quantitative data, the most important limitation of our study is that a representative sample of undocumented women is not feasible. Undocumented women in the Netherlands are nowhere registered, and only estimates about the size of different groups of undocumented women in the Netherlands exist. Therefore, conclusions should be drawn cautiously. Selection bias may have been introduced by the method used for recruiting the sample. For the qualitative data there were some limitations in the data collection. The interviews ideally should have been conducted in the women's own language by somebody of her own culture. Unfortunately, because of the diversity in origin this approach was not feasible. As a consequence we were confronted with several communication problems. Some women turned down official interpreters for security reasons and preferred translation by family members. This made in-depth interviews more difficult. It is likely that some experiences remained unmentioned. Furthermore, we decided not to audiotape the interviews in order not to lose the trust of the participants that are usually very concerned about their security.

The strength of this study is that female undocumented immigrants were personally interviewed about health care utilisation. This group is very difficult to recruit since they live in permanent threat of being arrested by the police and therefore hide in secret locations. As a consequence, policymaking for this group is often done without collecting and considering the opinions of the undocumented immigrants themselves. Our study gives clear information about the use of health care facilities and obstacles in accessing health care facilities based on the experience of undocumented female immigrants themselves, even from the women that refrain from seeking help and therefore are not included in most studies we mentioned before.

There are unmet health care needs among undocumented immigrants. This study shows that clearing institutional obstacles in accessing care alone is not enough to improve and guarantee the use of regular health care. Especially female labour migrants and women that came to the Netherlands for marriage and family reunion experience additional obstacles in accessing health care. These often 'invisible' groups, not known by any voluntary support organisation, need to be found, supported and informed about their rights, the health care system and the duty of professional confidentiality of doctors. Also health care providers need to be informed about existing legislation and explicitly instructed that they are obliged to provide care to these people.

Acknowledgments We wish to thank Margriet Straver for recruiting participants for the study and conducting the interviews, and we thank Hans Bor for statistical advice.

Conflict of interest statement We declare that we have no conflict of interest.

Open Access This article is distributed under the terms of the Creative Commons Attribution Noncommercial License which permits any noncommercial use, distribution, and reproduction in any medium, provided the original author(s) and source are credited.

\section{References}

Baghir-Zada R (2009) Illegal aliens and health (care) wants. The cases of Sweden and the Netherlands. Malmo University, Faculty of Health and Society, Malmo

Berk ML, Schur CL (2001) The effect of fear on access to care among undocumented Latino immigrants. J Immigr Health 3:151-156

Carballo M, Nerukar A (2001) Migration, refugees, and health risks. Emerg Infect Dis 7:556-560

Carballo M, Divino JJ, Zeric D (1998) Migration and health in the European Union. Trop Med Int Health 3:936-944

Caulford P, Vali Y (2006) Providing health care to medically uninsured immigrants and refugees. CMAJ 174:1253-1254

Creswell JW, Fetters MD, Ivankova NV (2004) Designing a mixed methods study in primary care. Ann Fam Med 2:7-12

Delvaux T, Buekens P, Godin I, Boutsen M (2001) Barriers to prenatal care in Europe. Am J Prev Med 21:52-59

DeSalvo KB, Fan VS, McDonell MB, Fihn SD (2005) Predicting mortality and healthcare utilization with a single question. Health Serv Res 40:1234-1246

Devillanova C (2007) Social networks, information and health care utilization: evidence from undocumented immigrants in Milan. J Health Econ

Gerritsen AA, Deville WL (2009) Gender differences in health and health care utilisation in various ethnic groups in the Netherlands: a cross-sectional study. BMC Public Health 9:109

Gerritsen AA, Bramsen I, Deville W, van Willigen LH, Hovens JE, van der Ploeg HM (2006) Use of health care services by Afghan, Iranian, and Somali refugees and asylum seekers living in The Netherlands. Eur J Public Health 16(4):394-399

Grove NJ, Zwi AB (2006) Our health and theirs: forced migration, othering, and public health. Soc Sci Med 62:1931-1942

Hall PL (2007) Health care for refused asylum seekers in the UK. Lancet 370:466-467

Hamburg (2010) Database on irregular migration. Working Paper No.4/2009. Hamburg Institute of International Economics

Hernandez-Quevedo C, Jimenez-Rubio D (2009) A comparison of the health status and health care utilization patterns between foreigners and the national population in Spain: new evidence from the Spanish National Health Survey. Soc Sci Med 69(3):370-378

Klazinga NS, Bloemen EJJM, van Buuren JJM, Goker E, Kortmann FAM, Legemaate J, Pronk CC, Schoenmakers JJ, Schwartz RV (2007) Arts en vreemdeling. Rapport van de commissie 
Medische zorg voor (dreigend) uitgeprocedeerde asielzoekers en illegale vreemdelingen (Doctor and foreigner. Report from the committee medical care for failed asylum seekers threatened with expulsion and illegal immigrants). Pharos, Utrecht

Kullgren JT (2003) Restrictions on undocumented immigrants' access to health services: the public health implications of welfare reform. Am J Public Health 93:1630-1633

Kulu Glasgow I, de Bakker D, Weide M, Arts S (2000) Illegalen aan de 'poort' van de gezondheidszorg: Toegankelijkheid en knelpunten in de zorg van huisartsen, verloskundigen en spoedeisende hulpafdelingen. (Illegal immigrants accessing health care: Accessibility and obstacles in the care from general practitioners, Midwifes and casualty departments). Nivel, Utrecht

Lanting LC, Bootsma AH, Lamberts SW, Mackenbach JP, Joung IM (2008) Ethnic differences in internal medicine referrals and diagnosis in the Netherlands. BMC Public Health 8:287

Nandi A, Galea S, Lopez G, Nandi V, Strongarone S, Ompad DC (2008) Access to and use of health services among undocumented Mexican immigrants in a US urban area. Am J Public Health 98:2011-2020

Okie S (2007) Immigrants and health care-at the intersection of two broken systems. N Engl J Med 357:525-529

PICUM (2007) Access to health care for undocumented migrants in Europe. PICUM: platform for international cooperation on undocumented migrants, Brussels

Reijneveld SA (1998) Reported health, lifestyles, and use of health care of first generation immigrants in The Netherlands: do socioeconomic factors explain their adverse position? J Epidemiol Community Health 52:298-304

Schoevers MA, van den Muijsenbergh ME, Lagro-Janssen AL (2009) Self-rated health and health problems of undocumented immigrant women in the Netherlands: a descriptive study. J Public Health Policy 30(4):409-422

Storwick L (2009) Accessing health care for undocumented immigrants. European observations. World Med J 55:13-16

Stronks K, Ravelli AC, Reijneveld SA (2001) Immigrants in the Netherlands: equal access for equal needs? J Epidemiol Community Health 55:701-707

Torres-Cantero AM, Miguel AG, Gallardo C, Ippolito S (2007) Health care provision for illegal migrants: may health policy make a difference? Eur J Public Health 17:483-485
Uiters E, Deville WL, Foets M, Groenewegen PP (2006) Use of health care services by ethnic minorities in The Netherlands: do patterns differ? Eur J Public Health 16:388-393

Uiters E, Deville W, Foets M, Spreeuwenberg P, Groenewegen PP (2009) Differences between immigrant and non-immigrant groups in the use of primary medical care; a systematic review. BMC Health Serv Res 9:76

United Nations National Assembly (1966) International convenant on Economic, Cultural and Social rights, art 12 (1) edn

UN economic saCRC (2000) General comment No. 14. The right to the highest attainable standard of health. UN Doc E/C. 12/2000/ 4. 2000 edn

van der Heijden PGM, van Gils G, Cruijff M, Hessen D (2006) Een schatting van het aantal in Nederland verblijvende illegale vreemdelingen in 2005 (An estimate of the number of illegal immigrants living in the Netherlands in 2005). Onderzoekscentrum IOPS. Universiteit Utrecht, Utrecht

van Herten, Reijneveld S, Borghouts J (2001) Financiering van zorg voor illegalen (financing of health care for illegal immigrants). TNO, Leiden

van Lindert, Droomers M, Wester GP (2004) Tweede Nationale studie naar ziekten en verrichtingen in de huisartspraktijk. Een kwestie van verschil: verschillen in zelf gerapporteerde leefstijl, gezondheid en zorggebruik. Nivel, Utrecht

van Oort, Kulu-Glasgow I, de Bakker D (2001) Gezondheidsklachten van illegalen: een landelijk onderzoek onder huisartsen en spoedeisende hulp afdelingen (health complaints of illegal immigrants: a national study). Nivel, Utrecht

Veenema T, Wiegers T, Deville W (2009) Toegankelijkheid van gezondheidszorg voor 'illlegalen' in Nederland: een update. (Accessibility of health care in the Netherlands for illegal immigrants: an update). Nivel, Utrecht

Wallace SP, Mendez-Luck C, Castaneda X (2009) Heading south: why Mexican immigrants in California seek health services in Mexico. Med Care 47:662-669

Wolff H, Epiney M, Lourenco AP, Costanza MC, DelieutrazMarchand J, Andreoli N, Dubuisson JB, Gaspoz JM, Irion O (2008) Undocumented migrants lack access to pregnancy care and prevention. BMC Public Health 8:93

Wu Z, Penning MJ, Schimmele CM (2005) Immigrant status and unmet health care needs. Can J Public Health 96:369-373 